\title{
THE EDUCATION OF WOMEN AND SEX EQUALITY
}

\section{By Gertrude S. Martin,}

Cornell University, Ithaca, N. Y.

The agitation for sex equality began, as Ellen Key has intimated, when Eve reached for the apple. It entered upon its final stage in modem civilized society when peace loving and indulgent, if somewhat sccptical, husbands, fathers, college boards, and school commissioners began at last gradually to yield, during the first half of the nineteenth century, to the nagging of their women folk and decided, albeit with many misgivings, to let them try their minds on the man's curriculum.

Up to that time the education of women both here and in Great Britain had been at best, except in the case of a few fortunate individuals, a thing of shreds and patches. At the beginning of the nineteenth century the great majority of our foremothers must have been nearly, if not quite, illiterate. In one direction only was the girl thoroughly and soundly trained. No pains were spared to perfect her in the manifold, if somewhat primitive, industrial processes carried on within the household; and if the processes themselves and the methods of instruction tended to develop only manual dexterity rather than mental capacity, they were nevertheless truly educative so far as they went. It must be admitted that it still remains for modern education to develop a technique equally well adapted to the present organization of the household.

Except in this direction, however, the education of women even at the close of the first quarter of the nineteenth century bad gone little, if any, beyond the point looked upon as desirable by the gentlemen of the court of Charles II, who "thought that women were educated enough if they could spell out the recipes of pies and puddings, the manufacture of which nature had entrusted to their tender mercies." It was not until 1852, as Miss Talbot has pointed out in her book on the Education of Women, that a public high school education of any kind was available for girls in Boston, and the opening of the Girls' Latin School in 1878 gave them their first opportunity to prepare for college. 
The story of the struggle for the education of women is beginning now to get itself told. Histories of the education of women in the United States or in particular states; biographies of leaders in the movement, such as Emma Willard, Mary Lyon, and Alice Freeman Palmer; magazine articles dealing with current phases of the educational problem--coeducation, the woman's college, vocational education-all these studies, issuing from the press in increasing numbers, are making it possible to trace with growing certainty the origin and tendencies of the movement. That means that one phase of it, at least, is fairly complete; that certain ideals that have been struggling for realization have at last got themselves established in our extermal social arrangements, and that the bearers of these ideals or their disciples now have a moment's breathing spell in which they can look back over the work and tell the rest of the world what the vision was that led them on and how it was wrought out into external reality.

They were quite clear in their minds as to what they wanted, these pioneers in the movement for women's education. Margaret Fuller made the classic statement of their demand:

It is not the transient breath of poetic incense that women want; each can receive that from a lover. It is not life-long sway; it needs but to become a coquette, a shrew, or a good cook, to be sure of that. It is not money, nor notoriety, nor the badges of authority which men have appropriated to themselves. If demands, made in their behalf, lay stress on any of these particulars, those who make them have not searched deeply into the need. The demand . . . . is for that which is the birthright of every being capable of recciving it, the freedom, the religious, the intelligent freedom of the universe to use its means, to learn its secret, as far as nature has enabled them, with God alone for their guide and judge.

To most men that sounded rankly heretical. To the few leaders of the thought of the age it was only the logical next step in the democratic movement already well under way. During the previous century great masses of men had been very busily and successfully engaged in making and enforcing this same demand for themselves against other men, those of the privileged classes; but when women, in their usual unforeseen and unforeseeable fashion, made this demand for themselves against men-likewise a privileged classthe latter at first stood somewhat aghast and then conscier tiously set in motion all the old forces of inherited belief, custom, and prejudice to oppose the spread of so pernicious a heresy. 
Doubtless every privileged class that ever existed has been frmly persuaded that the continuance of its privileges was necessary to the truest welfare of the community of which it formed a part. And where such a class does not use its powers too despotically, it often succeeds, partly by its moderation, partly because of the very sincerity of its belief in its own beneficence, in imposing a like belief upon considerable numbers of not too perspicacious persons who do not share its privileges. This is the explanation of the feminine anti-suffragists.

So now the leaders of this movement for the liberation of feminine personality found arrayed against them the powerful forces of conservatism. Most men and some women joined in the chorus of protest, admonition, warning, and appeal. "Remember," cries Mrs. Barbauld, an excellent lady of wide culture and no small talent, but without the gift of prophecy, addressing the budding womanhood of her time, "Remember, your best, your sweetest empire is to please." It is exactly the sort of advice that a Turkish odalisque might expect from a benevolent slave dealer. Half a century later, the eloquent Mr. Ruskin, sugar coating the pill, to be sure, in his own charming fashion, was still offering to his feminine readers in Great Britain mental physic of this sort:

All such knowledge should be given her [the girl] as may enable her to understand, and even to aid, the work of men: and yet it should be given, not as knowledge-not as if it were, or could be, for her an object to know; but only to feel and to judge.

\section{And again:}

A woman in any rank of life, ought to know whatever her husband is likely to know, but to know it in a different way. His command of it should be foundational and progressive, hers, general and accomplished for daily and helpful use. Speaking broadly, a man ought to know any language or science he learns, thoroughly, while a woman ought to know the same language, or science, only in so far as may enable her to sympathize in her husband's pleasures, and in those of his best friends.

Even granting Ruskin's underlying assumption in regard to the relation of the sexes- "He for God only, she for God in him"the sort of education he outlines would be wholly inadequate for the purposes indicated, but that is beside the point. What it is important to note is the fact that even while Ruskin was struggling to 
clothe his somewhat puerile and futile thought on the subject of the education of girls in language sufficiently beautiful, the Zeilgeist had passed on. At almost the same time on the other side of the water Matthew Vassar was meditating his great gift and formulating his profoundly simple statement of his belief in the right of women to absolute equality of opportunity with men. A few years more and hundreds of young women, and some older ones, were standing at the doors of higher institutions of learning everywhere, demanding or begging for admission according as their individual natures prompted.

In vain did timid feminine souls plead with these bolder, liberty loving sisters not to "unsex" themselves, not to throw away their lovely feminine charm for the empty bauble of a trained intellect, which would, besides, get them no husbands. Equally in vain did learned divines and distinguished statesmen and educators mark out for them the divinely set boundaries of woman's sphere, which they could pass only at their peril. They were too keenly conscious of themselves as individuals, too deeply aware of their capacity to know and to do, too driven by the irrepressible demand for self-expression, too completely caught, in short, in the great forward surge of the democratic movement, to turn back.

It has been accounted folly on the part of those early advocates of women's rights that they minimized sex differences; that they insisted upon the fundamental likenesses between men and women and ignored or denied the differences; that they conceived of sex equality as possible only through identity of training, activity, and function. They saw far more clearly than their critics. It was literally true that the only path to any general recognition of sex equality for all women, college trained or not, lay through the successful accomplishment by large numbers of women of the curriculum of the man's college, and subsequent successful work in fields traditionally assigned to men.

Old beliefs and prejudices die hard. In a world whose intellectual and religious leaders had debated solemnly, not so many centuries before, whether women really had souls, it is perhaps not to be wondered at that the masculine mind in general still clung tenaciously to the persuasion that where woman was concerned, man had been admitted to the counsels of the Almighty while woman herself had been carefully excluded; and that it was therefore his high duty and responsibility to determine the conditions under 
which her work for the world was to be done. The pioneers saw quite clearly that if the democratic movement was not to be aborted, was not to fail of its full fruition, another bit of mental surgery was inevitable. Men's minds must be opened a little further. The thonght of the last century must be carried to its logical conclusion. The belief that "men were created free and equal" and "had been endowed with certain inalienable rights" had, indeed, found firm lodgment in the social mind. That men meant women too was by no means so easily accepted. What was needed now was to compel a like general recognition of woman as an independent human personality, capable of determining her own ends, responsible for her own choices, and entitled to a voice in arranging the conditions of her life and work.

There was just one means to the accomplishment of that end. The mother sex might have gone on to the end of time training for and working at the mother task, under the old conditions prescribed by men, without either greatly improving the quality of their mothering or convincing men of their fitness for self direction. Nothing, indeed can fully win them that privilege except proved capacity to wrestle successfully with the same intellectual problems as men wrestle with, to do efficiently the same practical task, to keep pace with them in constructive thinking and creative work.

The first step in this "demonstration" is already fairly complete. Now and then some indiscreet professor or college president ventures to gencralize from his "impressions" and, like President Hyde in The College Man and the College Woman, delivers himself of the opinion that the college woman, so obviously superior in undergraduate work, betrays, as compared with men students, a lack of power to organize "facts in the light of the universal principles that bind them into systematic unity"-a power essential to productive scholarship. But hardly has he gotten himself into print to this effect when a Miss Talbot, or somebody like her, points out that out of the whole number of students taking the degree of doctor of philosophy at the University of Chicago prior to July 1909, 15.6 per cent were women, 8.9 per cent were of the rite grade, 10.8 per cent of cum laude, 15.5 per cent of magna cum laude, and 20.7 per cent of summa cum laude.

Such opinions as this of President Hyde are apparently based not on observed facts but on preconceived notions-traditional 
assumptions-as to the intellectual inferiority of women; and so long as these persist, particularly among those who should speak with authority, the woman's college is instinctively right in its sturdy maintenance of the principle that "there is no sex in mind," and in its steady refusal to introduce courses "to meet the special needs of women." Only when the rapidly accumulating achievements of women in fields heretofore almost monopolized by menachievements in literature, science, art, social and civic betterment, law, medicine, theology-shall at last have won men's respect so completely that they really come to believe the education of women to be a matter of as serious import as that of men, not merely for what it portends to the oncoming generation but for the service it can render directly through the educated individual herself-then only can we hope for any general recognition of sex equality.

Fcr the recognition of equality of any sort can be expected, after all, only where substantial equality exists; and there can be no question that, in actual achievement in most, if not all, fields of intellectual endeavor, women have in general lagged far behind their brothers. Eager and more or less resentful explanations of this fact are forthcoming on every hand, but woman's immediate task is not to explain the fact but to alter it. She forgets that only God can give credit for "what she aspired to be, and was not" because the demands of the race lay too heavy upon her, and that man's sentence can pass only on "the vulgar mass called 'work'-things done, that took the eye and had the price." Man on the other hand has inferred too readily from woman's non-performance of the tasks he has particularly valued her innate incapacity for performance. Hence this pretty quarrel of the sexes. It can be patched up when woman bas offered in abundant measure the proof that man demands, hardly before.

Now at last, however, education has put into her hands the means of furnishing that proof and she has not been slow in seizing her opportunity. Only a trifle more than two generations have passed since women gained general access to a more than rudimentary education, while the first generation of college women are just beginning to lay down their work; yet already, from field after field, has come the protest against the "woman's invasion." Whether these protests are just and reasonable, or whether they are the expression of blind prejudice, they are incontrovertible evi- 
dence of an extraordinarily rapid widening of the activities and influence of women.

The other day a volunteer committee of women, organized for the purpose of securing, if possible, the election of women delegates to the approaching constitutional convention in New York, issued a pamphlet setting forth briefly the services that trained women are rendering to the state in various fields, -in social work, both as employees of the state and as agents of volunteer, charitable, social, and civic organizations; in correctional work, as probation officers, superintendents of reformatories, etc.; in industry, as workers, as factory inspectors, as members of investigation commissions, as welfare workers, and as organizers of associations for the betterment of industrial conditions, such as the Women's Trade Union League and the Association for Labor Legislation; in education as teachers and superintendents and as pioneers in all the newer educational movements; in medicine, as practitioners and as leaders in the great public health movement through such means as tenement house inspection, medical inspection of school children, school nursing, abolition of the sweat shop, and the many activities carried on by such bureaus as that of child hygiene in the New York health department, which, under the leadership of a woman, maintains a staff of 196 medical inspectors and 650 trained nurses; in the civil service, in municipal and state boards - everywhere, an army of women called to serve the community in a large public way in spite of agelong tradition in favor of men for such service because, along with the trained mind and the balanced judgment, they could bring the woman's point of view, the woman's rich emotional experience, the woman's insight and quick intuition, qualities sorely needed and heretofore tragically lacking in our community dealings with some of the greatest of human problems.

In other fields also besides this of social service feminine achievement is growing apace, not in quantity only but in quality. More and more the work of women is coming to be judged by the same standards as that of men. More and more rarely do we hear a book, a picture, a bit of scientific investigation praised as "a remarkable piece of work for a woman." Gradually the world is coming to expect from women the same grade of work that it expects from men, and women know that every step in the growth of this expectation means for them an increase of opportunity. 
The old chivalry that was rooted in a belief in woman's mental and physical inferiority has served its purpose as a civilizing force and is rapidly passing - is so far outgrown, indeed, that, like many other survivals, it has already become a source of irritation and annoyance, sometimes even a social menace. Working side by side with women in school and in college, competing with them for academic prizes and losing quite as often as he wins, sitting with them on boards and commissions appointed to deal with great public questions and finding them possessed of a fund of expert knowledge, a depth and breadth of human sympathy, and a sanity of practical judgment often superior to his own, man has begun at last to see that if women have fallen short in the sort of achievement that the world has accounted great, the reason must be sought elsewhere than in an assumption of their intellectual inferiority. He begins dimly to understand that woman has been what she has through the ages-toiling slave and bearer of children, instrument of his individual pleasure and comfort-not because it pleased the gods to make him a superior creature to whom such services were due, but because this was nature's plan for preserving and humanizing and civilizing the race. Here and there he even begins to question vaguely whether, in nature's eyes, he has after all held the center of the stage, as he had supposed; whether woman has not all the while sat securely at the heart of things, laboring directly at the central task of all the ages, toward the accomplishment of which his labor also, all of it, is only a contribution, and for the most part only an indirect one. This uneasy doubt makes it impossible for him to speak with his former easy assurance about the limits of woman's sphere. What if there should prove to be no limits, or if the limits of the two spheres should coincide!

Woman, meantime, given command of the instruments of thought, is working her way slowly and sometimes painfully toward a solution of her peculiar problem-how to reconcile the conflicting claims of her own individuality and of the race. So far in the upward struggle she has unquestionably borne more than her fair share of the race burden. She is coming to believe now that the race needs for its perfection no longer the sacrifice but the full development of her individual gifts and powers, and she demands not that the race burden be lifted but that it be equalized. She begins to see that if her development has been one-sided, man's has been no less so, though in 
an opposite direction; and that what the race really needs is not more mothering but more fathering.

Perhaps it is a more or less definite recognition of the fact that sex equality can be achieved only by shifting to the man's shoulders a part of the race burden heretofore borne by the woman that makes him so wary of it; but he sealed his own fate when he yielded weakly to feminine wheedling in the matter of education. Nemesis is already at his heels. 